
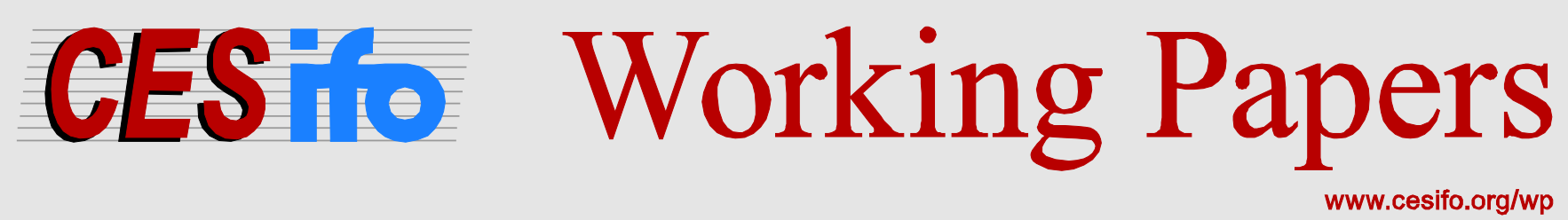

\title{
Taxing Multinationals in the Presence of Internal Capital Markets
}

\author{
Marko Koethenbuerger \\ Michael Stimmelmayr
}

\author{
CESIFO WORKING PAPER NO. 4353 \\ CATEGORY 1: Public FinANCE \\ JULY 2013
}
An electronic version of the paper may be downloaded
- from the SSRN website:
- from the RePEc website:
- from the CESifo website:
wWw.SSRN.com
www.RePEc.org
www.CESifo-group.org/wp

\section{CESifo}




\title{
Taxing Multinationals in the Presence of Internal Capital Markets
}

\begin{abstract}
There is ample evidence that internal capital markets incur efficiency costs for multinational enterprises (MNEs). This paper analyzes whether tax avoidance behavior interacts with the costs of running an internal capital market and how policies of competing governments respond to it. We show that the interaction in itself may lead to profit taxes that are too high (low) from a social perspective, provided the costs are attenuated (magnified) by higher profit taxes. We also show that internal efficiency costs might render infrastructure provision inefficiently low. Further, we clarify the implications of the MNE's decision to set up an internal capital market and the effect of external finance on the behavior of competing governments.
\end{abstract}

JEL-Code: H250, D210, F230.

Keywords: fiscal competition, multinational firms, internal efficiency costs, corporate finance, corporate tax avoidance.

\author{
Marko Koethenbuerger \\ Department of Management, Technology \\ and Economics \\ ETH Zurich \\ Weinbergstrasse 35 \\ Switzerland - 8092 Zurich \\ koethenbuerger@kof.ethz.ch
}

\author{
Michael Stimmelmayr \\ Center for Economic Studies \\ University of Munich \\ Schackstrasse 4 \\ Germany-80539 Munich \\ Stimmelmayr@lmu.de
}

This version: July 2013

We thank seminar and conference participants in Cambridge (RES, 2012), Copenhagen, Göttingen (VfS, 2012) Malaga (EEA, 2012), Munich, Bloomington (APET, 2011), and Uppsala (IIPF, 2010) for their valuable comments. Financial support through a grant from the European Policy Research Network (EPRN grant \#30570) and the German Science Foundation (DFG STI 619/1-1) is gratefully acknowledged. The usual disclaimer applies. 


\section{Introduction}

There is considerable evidence that cross-country tax rate differences incentivize multinational enterprises (MNEs) to adopt tax avoidance strategies. ${ }^{1}$ Compared to stand-along firms, they enjoy the advantage of being able to relocate capital and profits across their multiple divisions. MNEs may shift profits by strategically pricing internally traded goods and services or by using internal debt finance. Also, most MNEs run an internal capital market which allows the headquarter of the MNE to flexibly locate capital between divisions of the MNE in order to raise the overall profitability of the firm. ${ }^{2}$ The MNE can thereby exploit unforseen investment opportunities in divisions in the same way as relocating capital from high-tax countries to low-tax countries. $^{3}$

In this paper, we analyze how internal capital markets influence the incentives of governments to compete for capital. Unlike the existing literature on multinational taxation, we consider that an internal capital market does not only allow for a flexible allocation of capital (the so-called bright side of the internal capital market), but might also entail an efficiency cost for the MNE, frequently referred to as the dark side of internal capital markets. The paper thereby points out one significant concern of MNEs in reality. Consistent with this notion of frictions in internal capital markets, Lang and Stulz (1994) and Berger and Ofek (1995) find that conglomerates trade at a discount relative to comparable stand-alone firms that do not have access to an internal capital market. Similarly, business units of the conglomerate also overinvest and show a sensitivity of investment to Tobin's Q lower than that of matched stand-alone firms (Berger and Ofek, 1995; Rajan et al., 2000; and Ozbas and Scharfstein, 2010, among others). Glaser et al. (2012) empirically document that more powerful division managers influence internal decisions

\footnotetext{
${ }^{1}$ MNEs adjust investment behavior, the pricing of intra-firm trade or financial policy to exploit international tax differentials, see Hines (1999) and Gresik (2001), among others, for an overview of the literature. Egger et al. (2010) show that MNE face a significantly lower tax burden than comparable firms which do not have access to international tax avoidance strategies. On average, foreign ownership reduces the tax burden by about 56 percent. Mintz and Smart (2004) find multidivisional firms to have an elasticity of taxable income with respect to tax rates of 4.9, compared with 2.3 for other, comparable firms that are constrained in shifting income through the use of a consolidated corporate tax base.

${ }^{2}$ There are numerous highly publicised cases where MNEs internally relocate capital. For instance, car manufacturers such as Volkswagen or General Motors typically resize investments in their different production plants when new car models are added to the product line, where the most productive location produces the new car series at the expense of deinvestments in the remaining locations. Fiscal incentives might also be involved in decisions to internally relocate capital. Recently, Nokia closed its production in Bochum, Germany and moved it to Romania where the investment was eligible for subsidies while subsidy eligibility in Germany had expired.

${ }^{3}$ See, e.g., Hubbard and Palia (1999), Desai et al. (2005) and Egger et al. (2012) on the working of internal capital markets in MNEs and, in particular, Desai et al. and Egger et al. on how internal capital markets facilitate corporate tax avoidance.
} 
and receive larger capital allocations. The latter are not related to managerial ability or better investment opportunities, thereby reflecting an inefficiency in how capital is internally allocated. Relatedly, social connections to the CEO facilitate inefficient capital allocations in practice, in particular when corporate governance is weak (Dutchin and Sosyura, 2013).

In general, the way internal decisions are made influences firm behavior towards actors outside the firm such as competitors, consumers and also governments. In particular, we show that the dark side of internal capital allocations is in general not neutral for how governments decide on taxes that are levied on MNEs. Internal efficiency costs are responsive to taxes and the tax sensitivity of the costs may induce governments to adopt policies that are generically not associated with fiscal competition. In fact, the interaction between public policies and internal efficiency costs may counteract the downward pressure on taxes in fiscal competition and may incentivize governments to underprovide infrastructure goods. Internal efficiency costs influence government policy through changes in the size of the internal capital market (intensive margin), the decision whether to set up an internal capital market (extensive margin) and adjustments in external financing of the MNE.

We set up a model of a MNE with two divisions that are located in different countries. The two divisions are linked via an internal capital market that allows the headquarter to flexibly re-allocate resources across divisions in response to the arrival of new investment opportunities. Using an internal capital market incurs efficiency costs for the MNE. Division managers exert non-verifiable effort to generate cash flow. The headquarter has the residual control right over the use of this cash flow and may re-allocate it to the other division to enhance overall productivity or to reduce tax payments. Anticipating the reallocation of capital, managers exert less productive effort, thereby reducing firm value. Fiscal competition between the two jurisdictions influences (i) the capital allocation in the internal capital market and (ii) internal efficiency costs by changing effort provision of division managers. Both effects may have opposite implications for government incentives to compete for MNE profits. While the reallocation effect implies that taxes are inefficiently low through the standard positive tax competition externality, the effect that works through effort provision may result in inefficiently high profit taxes. In particular, division managers anticipate that an increase in the local tax rate induces the headquarter to reallocate resources to the other jurisdiction. This dilutes managerial incentives to be productive. In fact, a higher tax might increase internal efficiency costs which limits the other country's internal capital allocation and thereby its tax base. The implication of a negative tax base 
externality is in line with empirical findings in Becker and Riedel (2012). On the other hand, infrastructure provision reinforces incentives to exert effort, hence generating a positive fiscal externality. The latter finding stands in contrast to the prediction of conventional models of fiscal competition in which infrastructure provision lures capital away from other countries (e.g., Keen and Marchand, 1997). A MNE may also respond to government policy by setting up an internal capital market. Although an internal capital market allows a MNE to lower its tax obligation, the latter will not always decide to set up an internal capital market in response to higher taxes. The finding builds on an explicit modelling of the benefits and costs of organizational choices intended to avoid taxes, showing that a high level of infrastructure magnifies the negative effect of taxes on managerial effort provision. As such, a tax rise in a country with good infrastructure increases the efficiency costs of using an internal capital market. Finally, external finance by, e.g., shareholders might neutralize the influence of the dark side of internal capital markets on fiscal choices, but introduces a new source of inefficiency that works through internal capital allocations. A higher tax in one country reduces the amount of resources that shareholders are willing to provide. The shareholder response to higher taxes reduces the amount of capital that the headquarter allocates to each of the two divisions through the internal capital market. This generates a negative fiscal externality, independently of the magnitude of internal efficiency costs. These are absorbed by adjustments in external capital injections.

\subsection{Related literature}

Existing literature analyzes the investment behavior of MNEs from a different perspective. For instance, the common finding in models of tax competition is that tax policies of the host countries of a MNE and its divisions influence the investment allocation within the MNE. MNEs strategically allocate their investments across divisions and generically choose lower levels of investments in countries with higher taxes, see Hines (1997), Gresik (2001) and Griffith et al. (2010) for instance. The literature abstracts away from efficiency costs that are related to the allocation of investments within MNEs. ${ }^{4}$

\footnotetext{
${ }^{4}$ An alternative tax avoidance strategy of MNEs is to strategically price intra-firm trade (e.g., Haufler and Schjelderup, 2000). In such a setting, Elitzur and Mintz (1996) analyze how agency problems influence the behavior of governments in tax competition. The nature of the tax avoidance strategy and, also, the type of the internal efficiency costs differ from what we explore. Schjelderup and Schindler (2012) analyze how a conflict of interest between shareholders affects the strategic use of debt in MNEs to lower tax payments. Instead, we focus on real investment responses, non-aligned interests between division managers and the headquarter, and on the efficiency implications for non-cooperative tax rate choices.
} 
Internal capital markets and their disincentive effects are central to the corporate finance literature (e.g., Stein, 1997, Scharfstein and Stein, 2000, Brusco and Panunzi, 2005, and Inderst and Laux, 2005). The argument is that internal capital markets ensure an efficient allocation of resources across divisions. They, however, may undermine incentives by division managers to exert productive effort which results in lower division cash flow and/or less investment opportunities. ${ }^{5}$ Although this paper builds on the findings of this literature, we make a key distinction by considering the fiscal environment of MNEs. To the best of our knowledge, this is the first paper looking at how the two sides of the internal capital market influence fiscal policies of competing governments.

There is a growing body of literature that emphasizes the interaction between corporate tax avoidance and non-tax costs of tax aggressiveness that follow from the separation of ownership and control, see Chen and Chu (2005), Crocker and Slemrod (2005) and Desai and Dharmapala (2006, 2009), for instance. The overall conclusion from this literature is that tax avoidance might facilitate opportunistic behavior by managers such as managerial earnings manipulation or rent diversion. This paper shares the basic notion that tax avoidance incurs internal efficiency costs. We extend the literature by looking at MNEs and how internal efficiency costs connect policy choices of competing jurisdictions.

This paper also refers to the recent literature on the internal organization of MNEs and the role of public policy. For instance, Yeaple (2003) and Grossman et al. (2006) analyze how trade costs (being partly determined by public policy) influence the decision to serve foreign markets by exporting or by setting up a subsidiary. Antràs et al. (2009) shed light on the effect the quality of the legal system has on the benefits of setting up a multinational firm. Nielsen et al. (2008) look at how tax policy incentivizes firms to decentralize decision authority in an MNE in order to gain a competitive advantage in the product market. ${ }^{6}$ Bucovetsky and Haufler (2008) analyze the tax-sensitivity of the decision to set up a multinational firm structure that allows for tax savings through profit shifting. What sets this paper apart from previous ones is that it takes into account the aspect of corporate choice of the extensive and intensive margin of internal capital markets and considers how the organizational choice relates to government

\footnotetext{
${ }^{5}$ For an excellent survey of the theoretical and empirical literature on internal capital markets, see Gertner and Scharfstein (2013).

${ }^{6}$ Nielsen et al. (2010) point to the importance of the internal provision of inputs that are commonly used by MNE divisions for tax policy. We discuss the paper in detail in Section 4.
} 
incentives to compete for MNE profits. ${ }^{7}$

The paper is organized as follows. Section 2 presents the model. Section 3 analyzes the behavior of a MNE and of governments in the absence of managerial effort choices. Section 4 considers the effect of effort choices on MNE behavior and government tax policy. Section 5 turns to infrastructure policy. Section 6 analyzes the incentives to set up an internal capital market and the role of government policy while Section 7 considers the implications of external finance for the efficiency effects of internal capital markets. Section 8 provides a summary of the main results and draws some conclusions.

\section{Model}

We consider a multinational enterprise (MNE) with two divisions which are located in different countries. Each division is run by a manager who might exert effort to increase the profitability of the division. The motivation of managers might be differently modelled. As frequently mentioned in the literature on multinational taxation, it may be assumed that managers maximize the profit of the division, see Elitzur and Mintz (1996) and Nielsen et al. (2008), among others. Alternatively, division managers might be empire builders. The assumption that empire-building is central to the motivation of division managers conforms with the corporate finance view on how managers behave in MNEs with internal capital markets, see Stein (1997), Scharfstein and Stein (2000), Brusco and Panunzi (2003), and Inderst and Laux (2005), for instance. ${ }^{8}$ As a matter of choice, we adopt the latter approach, but should emphasize that the qualitative findings tend to be unaffected by the modelling choice. In Appendix A.2, we present a model with incentive wages for division managers. The results remain unchanged.

Hence, the division manager in country $i, i=1,2$, derives utility from the size of the division net of the cost of effort provision. Thus,

$$
u_{i}=\theta E\left(k_{i}\right)-\phi\left(e_{i}\right), \quad \theta>0
$$

$k_{i}$ denotes the size of the division, as measured by the capital stock, and $\phi\left(e_{i}\right)$ is the manager's cost of effort provision where $\phi\left(e_{i}\right)=(\omega / 2) e_{i}^{2}, \omega>0$. Effort is denoted by $e_{i}$ and is nonverifiable. The fact that $k_{i}$ enters the division manager's utility function reflects a desire to

\footnotetext{
${ }^{7}$ Matsusaka and Nanda (2002) and Inderst and Müller (2003) also explore the relation between internal capital markets and firm boundaries without, however, addressing managerial incentives and tax competition.

${ }^{8}$ Empirical evidence on empire building behavior in multi-divisional firms includes Glaser et al. (2012), for instance.
} 
build empires, as measured by the amount of capital that is employed in the division.

Each division starts with an investment project whose final return characteristics only become known in the course of time. In particular, the amount of capital employed by each division accumulates in two stages: At the first stage, each division's investment project generates cash flow, $x_{i}$. The manager may exert effort $e_{i}$ to increase the profitability of the investment and thereby the amount of cash-flow that is available in division $i$ at stage 1 (e.g., Brusco and Panunzi, 2003). The cash-flow production function is $x_{i}\left(e_{i}\right)=a_{i} e_{i}, a_{i}>0$. The locations of the two divisions might be asymmetric w.r.t. the capability to generate cash flow, i.e. $a_{i} \geq a_{j}$. The asymmetry may reflect differences in the levels of infrastructure or human capital that managers use in local production. We endogenize the productive endowment of the two countries in Section 5 .

The headquarter has the residual control right over the use of capital in the two divisions and may change the scale of the two investment projects after it has received new information on the profitability of the investment projects. Thus, the headquarter makes use of an internal capital market through which it is able to pool the divisions' cash flow and to allocate it across the two divisions, depending on their relative profitability. Similar to managers, the headquarter may be an empire builder (now with a focus on the total size of the MNE), but prefers to run an efficient empire. Hence, for a given amount of funds, it allocates funds to each division to equalize productivity differentials, as assumed.

Final output at stage 2 is given by ${ }^{9}$

$$
y_{i}=\alpha_{i} f\left(k_{i}\right)=\alpha_{i} k_{i}^{\beta} \text {, with } \alpha_{i}>0 \quad \text { and } \quad 0<\beta<1 \text {. }
$$

The productivity parameter $\alpha_{i}$ is stochastic ex-ante, i.e. at the beginning of period 1 . The headquarter only learns at the end of stage 1, after the two managers have decided on their effort levels, which division has the more profitable investment project. In line with the literature on internal capital markets, the headquarter has a comparative advantage in observing and using information on productivity realizations compared to shareholders or banks. The informational advantage is a source for creating value in the multidivisional firm by 'winner-picking' and thereby creates demand for an internal capital market to exist, see e.g. Stein (1997), Motta

\footnotetext{
${ }^{9}$ For the sake of simplicity, the first-stage cash-flow production function is linear in effort. Concavity of the second-stage production function is necessary to ensure that the headquarter continuously changes the capital allocation in response to tax policy. We abstract from managerial effort provision at the second stage, i.e. after the headquarter has redistributed capital, since second-stage effort levels would not be distorted by the internal capital market.
} 
(2003) and Gertner and Scharfstein (2013). The productivity realization take values $\bar{\alpha}>\underline{\alpha}>0$. Productivities are perfectly negatively correlated across divisions. ${ }^{10}$ With probability $p \in(0,1)$, division 1's project yields a higher return before tax, i.e. $\left(\alpha_{1}, \alpha_{2}\right)=(\bar{\alpha}, \underline{\alpha})$. With probability $1-p$, division 2 has the better project, $\left(\alpha_{1}, \alpha_{2}\right)=(\underline{\alpha}, \bar{\alpha})$.

Division $i$ 's profits are taxed at source at rate $\tau_{i} \cdot{ }^{11}$ Thus, expected profit of the multinational firm is

$$
E(\pi)=p\left[\left(1-\tau_{1}\right) \bar{\alpha} f\left(\bar{k}_{1}\right)+\left(1-\tau_{2}\right) \underline{\alpha} f\left(\underline{k}_{2}\right)\right]+(1-p)\left[\left(1-\tau_{1}\right) \underline{\alpha} f\left(\underline{k}_{1}\right)+\left(1-\tau_{2}\right) \bar{\alpha} f\left(\bar{k}_{2}\right)\right] .
$$

The variable $\bar{k}_{i}\left(\underline{k}_{i}\right)$ denotes the amount of capital the headquarter allocates to the highperforming (low-performing) division in country $i$.

The governments of the two countries compete for profits of the MNE divisions by setting the profit tax rates non-cooperatively. The tax proceeds in each country are spent on a public consumption good $g_{i}$ that is consumed by the local population.

In sum, the sequence of decisions is as follows: At stage 0, the two countries engage in fiscal competition and set their tax rates non-cooperatively. At stage 1, each division manager chooses the effort level $e_{i}$ which determines the amount of cash-flow $x_{i}$ in division $i$. At stage 2 , the headquarter learns the divisions' profitability and the headquarter re-allocates cash-flow $x_{1}+x_{2}$ across divisions so as to enhance the overall profitability of the MNE. Finally, production takes place and the firm is liquidated. We solve the game by backward induction.

\section{The bright side of internal capital markets}

We are interested in isolating the effect an internal capital market has on the efficiency of decentralized tax policy choices. In doing so, we first solve the model by assuming that managerial effort provision has no bearing on internal cash flow. The assumption implies that each division's cash flow, $x_{i}$, is independent of the level of effort provision, $e_{i}$, and is fixed at some exogenous positive level.

\footnotetext{
${ }^{10}$ When the two productivity parameters are perfectly positively correlated, the bright side of the internal capital market reduces to the advantage of adjusting investments in response to a different tax treatment of profits in the two countries.

${ }^{11}$ Despite the complexity of international tax treaties, there is a widely held presumption that the source principle of taxation is effectively in place. See Gresik (2001) for a review of tax principles that apply to MNEs. For instance, source-based taxes are influential when subsidiaries' profits are tax exempt in the country where the headquarter resides. Under a tax-credit system, tax credits for taxes already paid on repatriated profits are not neutral for the total tax liability of the MNE when the source tax rate is higher than the tax rate that applies upon repatriation. Also, for any tax principle, a time lag between taxation at source and repatriation of profits increases the effective role of source-based taxes for MNE behavior.
} 
At stage 2, the divisions' profitability is already revealed. Assume division $i$ is of high productivity and division $j$ is of low productivity, i.e. $\left(\alpha_{i}, \alpha_{j}\right)=(\bar{\alpha}, \underline{\alpha})$. The headquarter chooses the capital allocations $k_{i}=\bar{k}_{i}$ and $k_{j}=\underline{k}_{j}$ so as to maximize the overall profitability of the MNE. The headquarter thereby solves

$$
\begin{gathered}
\max _{\bar{k}_{i}, \underline{k}_{j}} \quad \pi \quad=\quad\left(1-\tau_{i}\right) \bar{\alpha} f\left(\bar{k}_{i}\right)+\left(1-\tau_{j}\right) \underline{\alpha} f\left(\underline{k}_{j}\right) \\
\text { s.t. } \quad x_{i}+x_{j} \geq \bar{k}_{i}+\underline{k}_{j} .
\end{gathered}
$$

The first-order condition is

$$
\left(1-\tau_{i}\right) \bar{\alpha} f^{\prime}\left(\bar{k}_{i}\right)=\left(1-\tau_{j}\right) \underline{\alpha} f^{\prime}\left(\underline{k}_{j}\right) .
$$

The headquarter reallocates capital so as to align the net-of-tax marginal productivity of capital across divisions. It is the allocative advantage associated with favoring well-performing divisions which is the bright side of the internal capital market. Given (2), the amount of capital allocated to each division is

$$
\bar{k}_{i}=\left(1+\left(\frac{\left(1-\tau_{j}\right) \underline{\alpha}}{\left(1-\tau_{i}\right) \bar{\alpha}}\right)^{\frac{1}{1-\beta}}\right)^{-1} X \quad \text { and } \quad \underline{k}_{j}=\left(1+\left(\frac{\left(1-\tau_{i}\right) \bar{\alpha}}{\left(1-\tau_{j}\right) \underline{\alpha}}\right)^{\frac{1}{1-\beta}}\right)^{-1} X,
$$

where $X=x_{i}+x_{j}$ is the total amount of cash flow the headquarter redistributes in the internal capital market. The high-performing division receives a larger share of cash flow $X$ relative to the share the low-performing division receives. The respective shares depend on the profit taxes in the two locations, the productivity parameters and the shape of the production function. Straightforwardly, a higher profit tax in the host country of a division reduces the share of the cash flow that is allocated to the division through the internal capital market, independently of its productivity realization. Also, the share the high-performing (low-performing) division receives is increasing (decreasing) in the productivity differential, $\bar{\alpha}-\underline{\alpha}$, and decreasing (increasing) in the concavity of the production function, as measured by $\beta$.

\subsection{Tax policy}

We assume that residents of country $i$ own a share $\gamma_{i} \in[0,1], \gamma_{1}+\gamma_{2}=1$, of the MNE and that managers reside outside the two countries. ${ }^{12}$ Under these assumptions, welfare of

\footnotetext{
${ }^{12}$ The latter assumption simplifies the analysis without invalidating the basic insights. Alternatively, we might assume that managers may reside in the country where they work, but that the number of managers in the population is relatively small. Hence, the policy-induced utility change of managers may be negligible relative to the change that the rest of the population experiences. With managerial incentive pay and a binding participation constraint for managers, the metric (7) is a comprehensive measure for welfare also when managers reside within the country, see Appendix A.2. The results are the same.
} 
country $i$ depends on MNE profits $\pi$, which accrue to residents of country $i$ at a rate $\gamma_{i}$, and on the residents' valuation of public consumption $g_{i}$, which is financed out of tax revenues $g_{i}=\tau_{i} \alpha_{i} f\left(k_{i}\right)$. Hence, expected welfare is

$$
\gamma_{i} E(\pi)+\lambda_{i} \tau_{i} E\left(T B_{i}\right) \quad \text { with } \lambda_{i}>1
$$

The parameter $\lambda_{i}$ is the citizens' valuation of public consumption and $E\left(T B_{i}\right)$ denotes the expected tax base in country $i$ which follows from multiplying the ex-post tax bases $\bar{\alpha} f\left(\bar{k}_{i}\right)$ and $\underline{\alpha} f\left(\underline{k}_{i}\right)$ by the relevant probabilities.

To analyze the efficiency of country $i$ 's tax policy, we characterize the externality a country's tax rate choice exerts on welfare in the neighboring country. Thereby, we analyze how tax policy choices differ from those which result from a coordination of tax policies between the two countries. The effect of country $i$ 's tax choice on country $j$ 's welfare is

$$
\gamma_{j} \underbrace{\frac{d E(\pi)}{d \tau_{i}}}_{<0}+\lambda \tau_{j} \underbrace{\frac{d E\left(T B_{j}\right)}{d \tau_{i}}}_{>0} .
$$

The first term marks a tax exporting effect: since a fraction $\gamma_{j}$ of the MNE is owned by citizens in country $j$, a share $\gamma_{j}$ of the drop in MNE profit is exported onto country $j$. This results in a standard tax exporting or ownership externality (Huizinga and Nielsen, 1997). Note, the change in MNE profits is only due to a mechanical effect. The reallocation of capital between divisions at stage 2 does not affect overall MNE profit, an implication that follows from an application of the envelope theorem.

The second term reflects the working of the internal capital market. Following a tax increase in country $i$, the headquarter reallocates cash-flow from country $i$ to country $j$, which enlarges the tax base in country $j$. Thus, the internal capital market generates a positive fiscal externality that, in itself, points toward undertaxation of profits in country $i$. It is this externality that is standardly related to the result of a "race to the bottom" in tax competition, in the sense that tax competition yields lower tax rates than coordination. We summarize the observations as follows:

Proposition 1: In the absence of managerial effort choices, an internal capital market induces capital reallocations in response to tax rate increases that generate a positive fiscal externality and a negative ownership externality. 
The overall efficiency implications of decentralized tax policy are ambiguous, reflecting the interplay of the two externalities. All these results are reminiscent of the standard notion of how decentralized tax policy affects the efficiency of tax rate choices (see Zodrow and Mieszkowski, 1986 and Huizinga and Nielsen, 1997, for instance). Unlike existing models of tax competition, the fiscal externality is mediated through the internal rather than external capital market of the firm.

\section{The dark and bright side of internal capital markets}

In this section, we additionally account for the disincentive effect of internal capital markets. At stage 2, the headquarter's behavior is exactly as before. The headquarter reallocates capital across the two divisions so as to maximize the overall profitability of the MNE. The implied firstorder condition is (5) and the associated capital allocation follows from (6). The only difference is that the amount of cash-flow in the internal capital market depends on the effort choice by division managers, changing the definition of total cash flow $X$ in Eq. (6) to

$$
X=a_{1} e_{1}+a_{2} e_{2}
$$

At stage 1, division managers choose the level of effort, which influences the amount of cash flow that is available in the two divisions. For instance, division manager 1 maximizes ${ }^{13}$

$$
\theta\left(p \bar{k}_{1}+(1-p) \underline{k}_{1}\right)-\phi\left(e_{1}\right) \quad \text { s.t. } \quad(6) \text { and }(9)
$$

The first-order condition of division manager 1's problem is

$$
\theta\left(p \frac{d \bar{k}_{1}}{d e_{1}}+(1-p) \frac{d \underline{k}_{1}}{d e_{1}}\right)-\phi^{\prime}\left(e_{1}\right)=0 .
$$

Using (6) and denoting $\bar{\delta}_{i}:=\bar{k}_{i} / X<1$ and $\underline{\delta}_{i}:=\underline{k}_{i} / X<1$ as the share of capital that is allocated to the high-performing and low-performing division in country $i$, the capital responses in (11) are

$$
\frac{d \bar{k}_{1}}{d e_{1}}=\bar{\delta}_{1} a_{1} \quad \text { and } \quad \frac{d \underline{k}_{1}}{d e_{1}}=\underline{\delta}_{1} a_{1}
$$

where $0<\underline{\delta}_{1}<\bar{\delta}_{1}<1$. The manager exerts effort up to the point where the change in the expected size of the division equals the marginal cost of effort provision. The first-order condition (11) captures the allocative disadvantage, i.e. the dark side of the internal capital

\footnotetext{
${ }^{13}$ The formulation for division manager 2 is analogous.
} 
market. Precisely, a rise in cash-flow in division 1 decreases its net-of-tax marginal productivity of capital. Given the strict concavity of the production function, the headquarter reallocates the rise in cash flow across the two divisions so as to align the net-of-tax marginal profitability of divisions. Effectively, division 1 loses a fraction $1-\underline{\delta}_{1}$ or $1-\bar{\delta}_{1}$ of self-generated cash-flow at the margin, depending on whether it has a low-performing or high-performing investment, c.f. (12). This dilutes managerial incentives to exert effort and lowers firm value (e.g., Scharfstein and Stein, 2000, Brusco and Panunzi, 2005, and Inderst and Laux, 2005).

\subsection{The MNE's responses to taxes}

The endogeneity of managerial effort choices opens up an additional channel through which tax policy influences the allocation of capital. In particular, tax policy influences effort choices and, thereby, the amount of cash flow $X$ which is shared between the two divisions. From (6), (9) and (11), the response in effort levels following a tax change is ${ }^{14}$

$$
\frac{d e_{i}}{d \tau_{i}}<0 \quad \text { and } \quad \frac{d e_{j}}{d \tau_{i}}>0 .
$$

A rise in $\tau^{i}$ lowers effort provision in country $i$ and increases it in country $j$. The intuition for the asymmetric response is that a rise in effort $e_{i}$ increases the amount of capital that the headquarter allocates to division $i$. The marginal return to effort interacts with the profit tax. A higher tax rate $\tau^{i}$ incentivizes the headquarter to allocate less capital to that country. This reduces the sensitivity of the capital allocation to effort provision and, thereby, the marginal return to effort in country $i$. On the contrary, the additional cash-flow allocated to country $j$ raises the marginal return to effort in this country and, thereby, the level of effort that the manager in country $j$ exerts. ${ }^{15}$

The variation in effort provision changes total cash flow, $X=a_{i} e_{i}+a_{j} e_{j}$. Using (6), (9) and (11), the aggregate cash flow response is ${ }^{16}$

$$
\frac{d X}{d \tau_{i}} \gtreqless 0 \text { iff } \quad a_{i}-a_{j} \lesseqgtr 0 .
$$

The productivity differential $a_{i}-a_{j}$ indicates the relative importance of the two divisions in generating cash flow within the MNE. When both countries are equally endowed with infrastructure $\left(a_{i}=a_{j}\right)$, the counteracting effects of a rise in the tax rate on the division managers'

\footnotetext{
${ }^{14}$ All effort and cash flow responses to taxation are derived in Appendix A.1.

${ }^{15}$ Note, using (6), the capital shares $\bar{\delta}_{i}$ and $\underline{\delta}_{i}$, which influence managerial incentives (c.f. (11) and (12)), decrease as $\tau_{i}$ rises and, conversely, increase as $\tau_{j}$ rises.

${ }^{16}$ See Appendix A.1 for a derivation.
} 
effort provision offset each other and total cash flow $X$ does not change with tax policy. The neutrality finding does not generalize to a situation in which divisions are asymmetrically important in generating cash flow. When $a_{i}>a_{j}$, the redistribution of cash-flow towards country $j$ implies a larger decline in the marginal return to effort for the division manager in country $i$ compared to the increase in the marginal return to effort that the division manager in country $j$ experiences. In response, the total amount of cash flow falls. The opposite conclusion holds when $a_{i}<a_{j}$.

To summarize,

Lemma 1: A rise in the profit tax rate $\tau_{i}$ lowers effort provision in division $i$ and raises effort provision in division $j$. In response, total cash flow rises (decreases) if division i is less (more) important in generating cash flow, i.e. $a_{i}<(>) a_{j}$. If both division are equally important in generating cash flow $\left(a_{i}=a_{j}\right)$, total cash flow is insensitive to taxation.

In line with empirical evidence (Ozbas and Scharfstein, 2010, and Gertler et al., 2012, for instance), the internal capital market incurs efficiency costs for the MNE. Tax policy interacts with the internal efficiency cost. It magnifies it when $d X / d \tau_{i}<0$ and attenuates it when $d X / d \tau_{i}>0 .{ }^{17}$ These internal changes influence tax choices, as analyzed in the next section.

\subsection{Tax policy}

In this section, we revisit the welfare effects of non-cooperative profit taxation. The objective function of government $i$ is (7) and the externality of its tax policy on country $j$ 's welfare is given by (8), which, for ease of readability, is repeated here:

$$
\gamma_{j} \frac{d E(\pi)}{d \tau_{i}}+\lambda_{j} \tau_{j} \frac{d E\left(T B_{j}\right)}{d \tau_{i}}
$$

The first term marks the ownership externality and the second term is the fiscal externality associated with country $i$ 's tax policy. From Lemma 1, we can already infer that the two externalities are qualitatively unchanged when $a_{i}=a_{j}$, just because taxes are neutral for the efficiency costs of the internal capital market. Albeit the dark side of the internal capital market lowers firm value, it has no implications for the marginal welfare effects of tax choices.

\footnotetext{
${ }^{17}$ More precisely, in stand-alone firms, $\bar{\delta}_{i}$ and $\underline{\delta}_{i}$ are equal to unity which strengthens effort provision, c.f. (11) and (12). Since for any $\tau_{i} \in[0,1]$ the shares are below unity in an internal capital market, changes in the costs of using an internal capital market will be attenuated or strengthened, but not eliminated by changes in taxes.
} 
When $a_{i} \neq a_{j}$, both types of externalities in (15) differ from those in the previous section. In what follows, we will dissect each externality type to isolate the impact of effort adjustments. The ownership externality in (15) summarizes two effects:

$$
\frac{d E(\pi)}{d \tau_{i}}=\left.\frac{\partial E(\pi)}{\partial \tau_{i}}\right|_{d X=0}+\frac{\partial E(\pi)}{\partial X} \frac{d X}{d \tau_{i}} .
$$

The response in MNE profits includes a mechanical and a behavioral response. The first term on the r.h.s. of (16) depicts the mechanical effect of a higher profit tax on MNE profits which is negative in sign. ${ }^{18}$ The second term captures the behavioral response that is due to the adjustment in managerial effort provision. From (14), a higher tax $\tau_{i}$ lowers aggregate effort provision when $a_{i}>a_{j}$. In response to this, the total amount of internal cash flow $X$ reduces and so does the profitability of the MNE. ${ }^{19}$ The negative effect on shareholder wealth spills over to the owners in country $j$ in proportion to their ownership share $\gamma_{j}$. A reversed result holds when $a_{i}<a_{j}$. Now, total cash flow increases following a tax rise and the effort-related ownership externality on county $j$ 's residents signs positive.

The fiscal externality term in (15) originates from two sources:

$$
\frac{d E\left(T B_{j}\right)}{d \tau_{i}}=\left.\frac{\partial E\left(T B_{j}\right)}{\partial \tau_{i}}\right|_{d X=0}+\frac{\partial E\left(T B_{j}\right)}{\partial X} \frac{d X}{d \tau_{i}}
$$

The tax base change reflects the tax-induced reallocation of capital to the division in country $j$ (first term on the r.h.s. of (17)), which positively affects country $j$ 's tax base, and the effect of a higher tax $\tau_{i}$ on internal cash-flow $X$ (second term). For $a_{i}>a_{j}$, the overall amount of cash-flow reduces. This lowers the capital allotments to both divisions and, thereby, country $j$ 's tax base, c.f. (6) and(14). ${ }^{20}$ The possibility of a negative tax base externality is in line with empirical findings in Becker and Riedel (2012). ${ }^{21}$ Differently, for $a_{i}<a_{j}$, total cash flow rises in response to a higher tax and so does the tax base in country $j$.

Hence, effort adjustments propagate through the internal capital market and systematically generate spill-overs. For $a_{i}>(<) a_{j}$, a tax rise $d \tau_{i}>0$ produces a negative (positive) externality on household income and on the tax base of country $j$. Thus, we can summarize:

\footnotetext{
${ }^{18}$ Note, by an application of the envelope theorem, the change in the capital allocation by the headquarter at stage 2 does not affect profits of the MNE, as before.

${ }^{19}$ From (3) and (6), the term $\partial E(\pi) / \partial X$ is positive since more internal cash flow increases MNE profits.

${ }^{20}$ Using $(6), \partial E\left(T B_{j}\right) / \partial X>0$. Higher cash flow increases the capital allocations of the two divisions, a positive tax base effect which follows from the concavity of the production function.

${ }^{21}$ Using data for European MNEs, Becker and Riedel (2012) find evidence that taxes in the parent country reduce affiliate investment abroad. A parent tax increase by ten percentage points dampens affiliate investment by 5.6 per-cent. This lowers taxable profits abroad.
} 
Proposition 2: Assume managers exert effort to produce cash flow. (i) When both countries are equally endowed with infrastructure $a_{i}$, the disincentive effect of the internal capital market is neutral for tax policy. Proposition 1 applies. (ii) When countries are differently endowed, the managerial behavior modifies the ownership externality and the fiscal externality. In particular, the disincentive effect of the internal capital market in isolation incentivizes the country that is more (less) amply endowed with $a_{i}$ to choose inefficiently high (low) profit taxes.

Adjustments in the non-tax costs of tax avoidance behavior of the MNE influence the efficiency of tax policy choices, depending on the differential $a_{i}-a_{j}$. Despite this systematic influence, Proposition 1 and 2 predict that the overall efficiency implications of tax policy remain ambiguous. However, the dark side of internal capital markets has the capacity to alter basic characteristics of tax policy equilibria that are central to policy debates. Absent internal efficiency costs (or their sensitivity to taxes) a country's tax rate might be inefficiently low, but it might be inefficiently high when internal efficiency costs matter. To illustrate this point, provided tax rate choices are efficient for some $a_{i}=a_{j},{ }^{22}$ a rise in $a_{i}$ generically results in an inefficient tax policy. The new tax rate $\tau_{i}$ might become inefficiently high. Otherwise, by symmetry, it is a drop in $a_{i}$ that implies an inefficiently high tax rate $\tau_{i}$. As such, for some small $\epsilon>0$, moving from $a_{i}-\epsilon$ to $a_{i}+\epsilon$ qualitatively alters the precise way of implementing tax coordination schemes or of designing a consolidated corporate tax base for MNEs, two policy measures against inefficient tax competition that are commonly discussed in the European Union and among OECD countries, for instance.

Proposition 2 points to a different source of asymmetry in capital tax competition than differences in population size, in per-capita capital endowments and in market size, which are predominantly analyzed in the literature (see Bucovetsky, 1991, Wilson, 1991, and Haufler and Wooton, 2010, among others). Even when $\lambda_{1}=\lambda_{2}$ and $\gamma_{i}=p=0.5$, the two countries will choose different profit tax rates, depending on the sign and magnitude of the differential $a_{i}-a_{j}$. The differential determines whether internal efficiency costs magnify or reduce in response to a higher tax in one of the two countries, as indicated by $d X / d \tau_{i}$, and thereby influences the

\footnotetext{
${ }^{22}$ Efficiency is obtained in a situation in which the ownership externality and tax base externality offset each other in equilibrium. For instance, efficiency holds for $\underline{\alpha}=\bar{\alpha}=\theta=\lambda=a_{i}=\omega=1, \beta=0.3$ and $\gamma_{i}=0.5$, among other parameter constellations.
} 
equilibrium tax rate $\tau_{i}$ that follows from the first-order condition

$$
\gamma_{i} \frac{d E(\pi)}{d \tau_{i}}+\lambda_{i}\left(E\left(T B_{i}\right)+\tau_{i} \frac{d E\left(T B_{i}\right)}{d \tau_{i}}\right)=0 .
$$

For instance, when $a_{i}>a_{j}$, the negative cash flow response $d X / d \tau_{i}$ reduces shareholder wealth in country $i$ in proportion to the ownership share $\gamma_{i}$ and lowers the profit tax base in country $i$. The effects work through the first term in (18), $d E(\pi) / d \tau_{i}$, and through the second term in brackets, $d E\left(T B_{i}\right) / d \tau_{i}$. The two terms are formally given by (16) and (17), when setting $i=j$, and the influence of the response $d X / d \tau_{i}$ on taxing incentives is captured by the second terms in these two equations. As such, the asymmetry $a_{i}>a_{j}$ reduces taxing incentives in country $i$ and, conversely, strengthens taxing incentives in country $j$. In general, with $\lambda_{1}=\lambda_{2}$ and $\gamma_{i}=p=0.5$, the equilibrium tax differential is $\tau_{i}<\tau_{j} .{ }^{23}$ The more productive country undercuts the less productive country in fiscal competition. ${ }^{24}$ The finding stands in contrast to the general notion that more productive countries find it easier to attract capital and set higher taxes in response, see Hindriks et al. (2008) and Black and Hoyt (1989), for instance. ${ }^{25}$

Nielsen et al. (2010) show that the provision of a common input (e.g., blue prints) by the headquarter of a MNE introduces a tendency to "overtax" local divisions. We should emphasize that the mechanism we propose here is different to the one underlying the choice of a common input. The cash provision by managers is akin to a private provision of a private good in a MNE, whereas the choice of common inputs by the headquarter is akin to a public provision of a public good. The two types of mechanisms lead to different outcomes. Whereas the cash provision in isolation may lead to inefficiently high or low taxes, the tax-efficient use of a common input unambiguously points towards overtaxation. ${ }^{26}$ Relatedly, the way the associated tax spill-overs

\footnotetext{
${ }^{23}$ This assumes that the first-order impact of the asymmetry $a_{i}>a_{j}$ on taxing incentives dominates. More precisely, the first-order condition (18) implicitly defines country $i$ 's best response $\tau_{i}^{*}\left(\tau_{j}\right)$. Starting at $\lambda_{1}=\lambda_{2}$, $\gamma_{i}=p=0.5$ and $a_{i}-a_{j}=0$, an increase in $a_{i}$ shifts country $i$ 's best response downward in $\left(\tau_{j}, \tau_{i}\right)$ space. With equilibrium stability, this lowers country $i$ 's tax rate, implying $\tau_{i}-\tau_{j}<0$, ceteris paribus. At the same time, the rise in $a_{i}$ shifts country $j$ 's tax rate outward in $\left(\tau_{j}, \tau_{i}\right)$ space. Relative to the initial stable equilibrium, country $j$ 's tax rate rises. However, considering the shift in both countries' best responses, the equilibrium tax differential $\tau_{i}-\tau_{j}$ only becomes negative when the tax rate changes that directly result from the shift in the best responses are not overturned by repercussions in the tax rate choices that follow from the strategic complementarity or substitutability of tax rates.

${ }^{24}$ With unrestricted parameter values of $\lambda_{i}, p$ and $\gamma_{i}$, the tax differential $\tau_{i}-\tau_{j}$ is predicted to narrow, when it is positive with $a_{i}=a_{j}$, and to widen otherwise.

${ }^{25}$ Hindriks et al. (2008) shows that a higher level of public infrastructure allows governments to set higher profit taxes. Black and Hoyt (1989) are exemplary for the literature on bidding for FDI, showing that a country can set a higher tax on mobile firms to the extent that it offers locational advantages (such as a higher factor productivity) relative to its closest competitors.

${ }^{26}$ Nielsen et al. (2010) and this paper accommodate the empirical finding of a negative tax base externality that is mediated through MNEs, see Becker and Riedel (2012). In Section 7, we show that, in the presence of external finance, the tax base externality is unambiguously negative in sign.
} 
operate between countries is through the relocation of capital in the present paper and the complementarity of production factors (capital and the common input) in Nielsen et al.

\section{$5 \quad$ Infrastructure investment}

In this section, we endogenize the amount of infrastructure that each region non-cooperatively provides. We consider two types of infrastructure spending: one that enhances the productivity of effort provision, as measured by $a_{i}$, and one that increases the productivity of capital that is used in each division to produce output. To incorporate the latter, we rewrite the term $\alpha_{i}$ in the production function $y_{i}=\alpha_{i} k_{i}^{\beta}$ as $\alpha_{i}=\tilde{\alpha}_{i} A_{i}$. $\tilde{\alpha}_{i}$ is a stochastic productivity parameter (with the same properties as before) and $A_{i}$ is a policy variable to be chosen by region $i{ }^{27}$ With this modification, expected public consumption reads $E\left(g_{i}\right)=\tau_{i} E\left(T B_{i}\right)-a_{i}-A_{i}$ where the price of infrastructure is normalized at unity. Stage 0 of the game now involves the two countries to engage in fiscal competition by setting tax rates and infrastructure spending non-cooperatively. The other stages of the model are the same as in the previous section.

We first turn to the choice of $a_{i}$. Following (6), (9), and (11), the effect of a rise in $a_{i}$ on effort provision is

$$
\frac{d e_{i}}{d a_{i}}>0 \quad \text { and } \quad \frac{d e_{j}}{d a_{i}}=0
$$

Intuitively, a rise in $a_{i}$ raises the marginal return to effort of the manager in division $i$, while leaving the marginal return to effort for the manager in division $j$ unchanged.

The effect of a higher productivity $a_{i}$ on the amount of capital that each division receives through the internal capital market is

$$
\frac{d k_{l}}{d a_{i}}=\left.\frac{\partial k_{l}}{\partial a_{i}}\right|_{d e_{i}=0}+\frac{\partial k_{l}}{\partial e_{i}} \frac{d e_{i}}{d a_{i}}>0 \quad l=1,2 .
$$

Note, from (6) and (9), $\partial k_{l} /\left.\partial a_{i}\right|_{d e_{i}=0}>0$ and $\partial k_{l} / \partial e_{i}>0$. The total effect can be decomposed in a direct effect that follows from the rise in $a_{i}$ for a given level of effort, as captured by the first term on the right-hand side of (20). More capital is available in the internal capital market that can be shared between the two divisions. As captured by the second term, the rise in effort provision in division $i$ additionally expands the pool of cash flow that benefits the two divisions through the internal capital market.

\footnotetext{
${ }^{27}$ One might think of $a_{i}$ as a metric that measures the extent to which creative firm clusters, which are fostered by public policy, make managers more productive, while $A_{i}$ might capture public infrastructure or governmentsupported technological innovations.
} 
Thus, we can summarize:

Lemma 2: (i) A rise in the productivity of generating cash flow in division $i, a_{i}$, raises effort provision in division $i$ and leaves incentives to exert effort in division $j$ unchanged. (ii) Following a rise in infrastructure provision $a_{i}$, both divisions receive more capital through the internal capital market due to the direct effect of higher infrastructure provision and the associated managerial incentive effect.

At stage 0 , government $i$ chooses $a_{i}$ to maximize welfare of the local population. The welfare measure is (7), modified to account for infrastructure spending:

$$
\gamma_{i} E(\pi)+\lambda_{i}\left(\tau_{i} E\left(T B_{i}\right)-a_{i}-A_{i}\right) \quad \text { with } \quad \lambda_{i}>1 .
$$

Tax revenues net of infrastructure expenditure are spent on the domestic consumption good that is valued by local residents at rate $\lambda_{i}>1$ per unit of consumption spending.

In order to single out the implications of the disincentive effect of the internal capital market for the efficiency of decentralized policy choices, we look at the impact of country $i$ 's infrastructure policy on welfare in country $j$ :

$$
\gamma_{j} \frac{d E(\pi)}{d a_{i}}+\lambda_{j} \tau_{j} \frac{d E\left(T B_{j}\right)}{d a_{i}} .
$$

Disentangling the first term in (22), the effect on the profits of the multinational firm is

$$
\frac{d E(\pi)}{d a_{i}}=\left.\frac{\partial E(\pi)}{\partial a_{i}}\right|_{d e_{i}=0}+\frac{\partial E(\pi)}{\partial e_{i}} \frac{d e_{i}}{d a_{i}}>0 .
$$

The first term is the positive mechanical effect of a higher infrastructure spending on MNE profit. Internal efficiency costs add a second effect. The rise in effort in country $i$, which follows from infrastructure provision, equally increases profits which partially accrue to residents in county $j$.

As to the tax base change in country $j$, we find

$$
\frac{d E\left(T B_{j}\right)}{d a_{i}}=\left.\frac{\partial E\left(T B_{j}\right)}{\partial a_{i}}\right|_{d e_{i}=0}+\frac{\partial E\left(T B_{j}\right)}{\partial e_{i}} \frac{d e_{i}}{d a_{i}}>0 .
$$

A more generous infrastructure spending $a_{i}$ directly increases the capital allocation in country $j$, as captured by the first term. The associated rise in tax revenues is reinforced through the 
effort increase in country $i$, c.f. second term in (20) and (24). Thus, we can summarize:

Proposition 3: In an uncoordinated equilibrium, infrastructure spending $a_{i}$ generates a positive ownership and fiscal externality. In particular, the two externalities are positive in the absence of discretionary behavior by managers and are both reinforced through the change in managerial behavior in response to infrastructure spending $a_{i}$.

Proposition 3 shows that infrastructure spending is inefficiently low in competition for MNE profits. The result differs from the conventional finding that infrastructure spending generates a negative fiscal externality in fiscal competition, see Keen and Marchand (1997), for instance. According to them, countries use infrastructure spending to lure more capital to the jurisdiction, at the expense of capital investments in other countries. An internal capital market modifies the sign of the spill-over. It generates a positive spill-over on tax revenues since the return to infrastructure policy (higher cash flow) is shared between the two divisions through the reallocation of capital by the headquarter.

The uncoordinated Nash equilibrium is inherently asymmetric w.r.t. the level of infrastructure $a_{i}$ in each country. Most notably, the ownership share, $\gamma_{i}$, and the preference for public consumption spending, $\lambda_{i}$, may differ across countries and so will the amount of infrastructure each country provides in equilibrium. An equilibrium infrastructure differential $a_{i}-a_{j} \neq 0$ renders the total amount of effort sensitive to tax rate changes, c.f. (14). In consequence, managerial behavior generically influences the uncoordinated equilibrium choice of profit taxes, as summarized by part (ii) and (iii) of Proposition 2.

The second type of infrastructure $A_{i}$ enhances the productivity of the amount of capital that is finally allocated to division $i$, rather than increasing the amount of capital that is available in the internal capital market for redistribution. Inserting $\alpha_{i}=\tilde{\alpha}_{i} A_{i}$ into (5) shows that, since an increase in $1-\tau_{i}$ is equivalent to a rise in $A_{i}$ in terms of the impact on divisional capital budgets, the response in $k_{i}$ to changes in $A_{i}$ is opposite in sign to the response that follows from changes in $\tau_{i}$. The effect of taxes on managerial effort choices work through the ex-post adjustment in capital only. Thereby, the response of managerial effort choices to $\tau_{i}$ and $A_{i}$ are opposite in sign as well. Using $X=a_{1} e_{1}+a_{2} e_{2}$, this implies

$$
\frac{d X}{d A_{i}}=-\frac{d X}{d \tau_{i}}
$$


Combining (25), Lemma 1 and Proposition 2, we find:

Proposition 4: In an uncoordinated equilibrium with $a_{i} \neq a_{j}$, the disincentive effect of the internal capital market in isolation incentivizes the country with the higher level of $a_{i}$ to choose an inefficiently low (high) level of infrastructure spending $A_{i}$. If $a_{i}=a_{j}$ in equilibrium, the efficiency of infrastructure provision $A_{i}$ is not affected by the disincentive effect of the internal capital market.

Unlike country $i$ 's tax policy, infrastructure spending $A_{i}$ increases shareholder wealth in country $j$ and lowers country $j$ 's tax base, absent managerial effort choices. Phasing in Proposition 4, the overall efficiency implications of infrastructure spending $A_{i}$ are opposite in sign to the implications of profit taxation, which are characterized in Section 3 and 4. The finding is in line with the general notion that profit taxes and infrastructure services are differently used in fiscal competition (e.g., Keen and Marchand, 1997), but differs nevertheless from it in an important way. Profit taxes might be inefficiently high, while infrastructure spending might be inefficiently low, and this qualitative difference is related to the disincentive effect of the internal capital market.

\section{Choosing to set up an internal capital market}

Headquarters may decide on how strongly divisions are financially integrated through an internal capital market. For instance, divisions may operate on a stand-alone basis where investment outlays are only financed by, e.g., retained earnings of the division. In this case, the headquarter loses the flexibility to reallocate funds in response to productivity shocks in each division, but also saves on efficiency costs inherent to an internal capital market. In this section, we analyze the incentive by MNEs to create an internal capital market and how the incentive relates to profit taxation. ${ }^{28}$ Consider a continuum of MNEs which differ w.r.t. the range of the productivity

\footnotetext{
${ }^{28}$ The decision is equivalent to the choice of committing not to interfere with the capital allocation after information on the profitability of each division becomes available. Headquarters may do so by refraining from obtaining information on the profitability of each division. For instance, this can be accomplished by not assigning resources to the headquarter ex-ante that are necessary to learn about productivity differentials ex-post and to resize investment projects in response. In such a MNE, decision authority would exclusively lie with divisions. See, e.g., Mookherjee (2006) for an analysis of how information influences the (de)centralization of decision authority in firms, and Acemoglu et al. (2007) for empirical work on the relation between decentralization of decision authority in firms and the amount of information headquarters might use.
} 
differential $\Delta=\bar{\alpha}-\underline{\alpha}$. The productivity differential is distributed on $[0, \bar{\Delta}]$ with density $g(\Delta)>0$ for $\Delta \in[0, \bar{\Delta}] . \Delta$ indicates the magnitude of the productivity gain associated with a relocation of capital through an internal capital market. The model extension reflects the observation that firms might operate in differently risky business environments and, hence, are exposed to a different range of productivity shocks. ${ }^{29}$

The sequence of decisions is as follows: At stage 0, the two jurisdictions engage in fiscal competition and set their tax rates non-cooperatively. At stage 1, each multinational headquarter decides whether to set up an internal capital market. At stage 2, each division manager chooses the effort level $e_{i}$ which determines the amount of cash-flow $x_{i}$ in division $i$. At stage 3 , the headquarter learns the divisions' profitability and, provided an internal capital market has been set up at stage 1 , the headquarter re-allocates cash-flow $x_{1}+x_{2}$ across divisions so as to enhance the overall profitability of the MNE. Finally, production takes place and the firm is liquidated. We solve the game by backward induction.

We first turn to the managerial effort choices in a MNE without an internal capital market. For instance, division manager 1 solves

$$
\max \theta\left(p \bar{k}_{1}+(1-p) \underline{k}_{1}\right)-\phi\left(e_{i}\right) \quad \text { s.t. } \quad \bar{k}_{1}=\underline{k}_{1}=a_{1} e_{1} .
$$

The first-order condition is $\theta\left(p a_{1}+(1-p) a_{1}\right)-e_{1}=0$ and the optimal effort level is $e_{1}=\theta a_{1}$. Two observations immediately emerge. First, managers do not have to share the return to effort with the other division through an internal capital market. In response, they will exert more effort, a positive incentive effect that is the mirror image of the dark side of the internal capital market. ${ }^{30}$ Second, the managerial choice problem is independent of profit taxes and so is the managerial effort choice and the level of gross profits in each division. Division manager 2's decision problem is analogous in structure.

Denoting the expected profit level before taxes of a stand-alone division and of a division that is integrated in an internal capital market (see Section 4) by $E\left(\Phi_{i}^{S}\right)$ and $E\left(\Phi_{i}^{I}\right)$, respectively, the headquarter decides to set up an internal capital market if and only if

$$
\left(1-\tau_{i}\right) E\left(\Phi_{i}^{S}\right)+\left(1-\tau_{j}\right) E\left(\Phi_{j}^{S}\right)<\left(1-\tau_{i}\right) E\left(\Phi_{i}^{I}\right)+\left(1-\tau_{j}\right) E\left(\Phi_{j}^{I}\right)
$$

\footnotetext{
${ }^{29}$ Benefit heterogeneity might also be related to the quality of information headquarters have access to and the way they can implement policy changes across divisions due to information processing and communication costs. See Mookherjee (2006) for a review of the literature.

${ }^{30}$ Note, using (12), the first-order condition (11) can be rewritten to $\theta\left(p \bar{\delta}_{1} a_{1}+(1-p) \underline{\delta}_{1} a_{1}\right)-e_{1}=0$ where $0<\underline{\delta}_{1}<\bar{\delta}_{1}<1$.
} 
Since MNEs differ w.r.t. the range of the productivity realization $\bar{\alpha}-\underline{\alpha}$, those MNEs which operate in industries with a high productivity differential opt for an internal capital market. Their benefit of equalizing the marginal productivity of capital (net of tax) across divisions is high relative to the costs of diluted managerial incentives to generate cash flow. ${ }^{31}$ To analyze how the decision to set up an internal capital market is affected by profit taxes, we differentiate both sides of (27) w.r.t. the profit tax in country $i:^{32}$

$$
-E\left(\Phi_{i}^{S}\right) \gtreqless-E\left(\Phi_{i}^{I}\right)+\left(\left(1-\tau_{i}\right) \frac{d E\left(\Phi_{i}^{I}\right)}{d X}+\left(1-\tau_{j}\right) \frac{d E\left(\Phi_{j}^{I}\right)}{d X}\right) \frac{d X}{d \tau_{i}} .
$$

The first term on both sides of inequality (28) is the mechanical effect of a higher tax $\tau_{i}$. The second term on the right-hand side captures the role of effort provision and its effect on cash flow $X$. Taking the latter effect in isolation, more firms will opt for an internal capital market provided total cash flow rises with the profit tax and vice versa. ${ }^{33}$ As shown in Section 4, the response in aggregate cash flow of the MNE is positive if $a_{i}<a_{j}$ and negative if $a_{i}>a_{j}$, c.f. (14). We can hence summarize the influence of effort choices on the extensive margin as follows:

Lemma 3: Following a tax rise in country $i$, the disincentive effect of internal capital markets incentivizes MNEs to set up (not to set up) an internal capital market when country $i$ is relatively poorly-endowed (amply-endowed) with infrastructure, i.e. $a_{i}<(>) a_{j}$. With a symmetric endowment, $a_{i}=a_{j}$, changes in managerial behavior are neutral for the organizational decision of MNEs.

Lemma 3 predicts that MNEs will less likely opt for an internal capital market when the country in which the tax is raised is relatively amply endowed with infrastructure. Intuitively, using an internal capital market entails the costs of diluted managerial incentives and a tax rise in the more amply-endowed country increases these costs. Lemma 3 might be surprising. An internal capital market provides more flexibility in avoiding taxes. One may therefore expect that MNEs will expand their options to avoid taxes when the profit tax rate rises. ${ }^{34}$ The finding

\footnotetext{
${ }^{31}$ We assume that $\bar{\Delta}$ is sufficiently large so that the cut-off differential $\Delta^{*}$, at which a MNE is indifferent, is interior, i.e. $\Delta^{*} \in(0, \bar{\Delta})$.

${ }^{32}$ Expected profits $E\left(\Phi_{i}^{I}\right)$ and $E\left(\Phi_{j}^{I}\right)$ are affected by the relocation of capital by the headquarter. Its effect on profits when $\tau_{i}$ is increased drops out due to an application of the envelope theorem and, in consequence, does not show up on the right-hand side of (28).

${ }^{33}$ Note, $d E\left(\Phi_{i}^{I}\right) / d(X)>0$ since a larger cash-flow pool benefits all divisions.

${ }^{34}$ The finding may be the result of a reduced-form reasoning of tax avoidance behavior. The cost of using tax
} 
in this paper is based on a structural modelling of the costs and benefits of using organizational forms that allow for tax savings. It thereby allows for a more detailed comparative static analysis, unravelling more comprehensive and possibly unexpected interdependencies.

Generous infrastructure provision creates a second, policy-related dark side of internal capital markets. An internal capital market not only undermines incentives to exert effort, for a given level of taxes, but also reduces total effort provision in response to a tax hike in the amply-endowed location. As such, it appears that, in particular, high-tax countries with good infrastructure will host divisions which are less financially-integrated with other divisions of the MNE. The prediction bears resemblance to previous explanations of how tightly divisions are financially integrated. Internal capital markets may serve as a substitute to a malfunctioning external capital market that local divisions would have to resort to otherwise (Desai et al., 2005). To the extent that a poor infrastructure positively correlates with the quality of the local capital market, both explanations tend to suggest that divisions in countries with a lower institutional quality are integrated in an internal capital market.

In this setting, internal efficiency costs influence policy externalities through two decision margins of the MNE. From Proposition 2 and 4, a tax rise in a poorly-endowed country incentivizes more MNEs to create financial linkages between divisions. Those MNEs with an internal capital market also have a larger cash flow pool following the tax rise. The adjustments in the extensive and intensive margin positively spill over to the amply-endowed country in form of higher shareholder wealth and of a larger profit tax base.

Proposition 5: Following a tax rise in country $i$, the effort-related adjustments in the intensive margin and extensive margin of an internal capital market reinforce each other, and tend to reduce (increase) the profit tax rate below (above) the efficient level when country $i$ is relatively poorly-endowed (amply-endowed) with infrastructure, i.e. $a_{i}<(>) a_{j}$. In the absence of a productivity differential, $a_{i}-a_{j}=0$, the intensive margin and extensive margin of an internal capital market are shielded from adjustments in managerial effort provision and so are taxing incentives of governments.

avoidance strategies is frequently summarized by a cost function that is convex in the extent of tax avoidance. With this specification, higher taxes lead to more tax avoidance in the tax-raising jurisdiction, either through more intense profit shifting or through organizational changes that allow for tax savings. 
Looking at overall efficiency of tax rate choices, a MNE that does not run an internal capital market gives rise to a negative mechanical tax-exporting externality only, while a MNE that runs an internal capital market generates an externality that is ambiguous in sign, c.f. (16) and (17). Hence, with an endogenous number of financially-integrated MNEs, a tax hike generates an ambiguous policy externality in aggregate.

\section{External Finance}

In Section 3 and 4, corporate capital is internally generated or inherited from the past (due to historical capital injections). In either case, retained earnings are the prime source of funds for investments in each division, as generally assumed in the literature on internal capital markets (e.g., Stein, 1997, Scharfstein and Stein, 2000, Brusco and Panunzi, 2005, and Inderst and Laux, 2005). In the following, we allow external finance to be endogenously determined by shareholders. ${ }^{35}$ The model extension is particularly descriptive of MNEs in fast growing markets in which capital demand is in excess of internally generated or historically injected funds. As until now, we assume that the headquarter has an informational advantage in observing the productivity realization in the divisions (which creates demand for an internal capital market to exist). Shareholders know the distribution from which the productivity in each division follows. They may inject capital that the headquarter distributes among the two divisions, along with internally generated cash flow, after the headquarter has gotten to know the productivity level in each division. In essence, shareholders have no direct control over resource allocation and need to resort to the headquarter to channel external capital toward divisions, see Motta (2003) and Gertner and Scharfstein (2013), among others. ${ }^{36}$

To analyze the role of external finance for the working of internal capital markets and the implications for government policy, we extend the decision sequence in Section 2. We assume that shareholders decide on the amount of capital injections $K$ at stage 0.5, i.e. after governments have decided on the level of taxes, but before managers decide on the level of effort at stage 1. The headquarter gets to know the productivity of the two divisions at stage 2 and internally

\footnotetext{
${ }^{35}$ Motta (2003) and Inderst and Müller (2003) also explore the relation between internal and external finance without, however, addressing the role of taxes and the incentives of government to compete for profits.

${ }^{36}$ External capital might take the form of equity or debt. Shareholders may provide own-source funds in form of equity or debt, as in Motta (2003), or attract funds from external investors by new share issue or debt finance, as in Holmstrom and Tirole (1997). In general, shareholders might have a preference for one or the other form of finance due to a different tax treatment of debt and equity. Such a tax preference would not change the basic mechanism we are analyzing in this paper.
} 
allocates capital. The adjusted sequence of decisions reflects the view that corporate finance might change following tax changes and that internal decisions will adapt to the new financial situation.

Working backwards, the headquarter has a pool of capital at stage 2 that comprises external capital $K$ and internally generated cash flow $x_{1}+x_{2}$. Denoting the total pool of resources that is allocated through the internal capital market by $\hat{X}=K+x_{1}+x_{2}$, the capital allocation the headquarter chooses follows from (6). At stage 1, managers choose effort and, in doing so, they compare the marginal return to effort with the marginal cost, c.f. (11). The former is given by the expected share of the pool of resources times the marginal increase in $\hat{X}$ that follows from a rise in effort. Both effects are independent of $K$ and so is the level of effort provision. Hence, external capital does not crowd out internal cash flow. It increases the size of the internal capital market $\hat{X}$ one by one.

At stage 0.5 , shareholders choose $K$ so as to maximize expected MNE profit $E(\pi)$, as given by (3) where $X$ is replaced by $\hat{X}$, net of the opportunity costs of external capital. Denoting the opportunity costs of capital injections by $r$, the board of shareholders solves

$$
\max _{K} E(\pi)-r K \quad \text { s.t. } \quad(6) \quad \text { and } \quad \hat{X}=K+x_{1}+x_{2} .
$$

Using (5), the first-order condition for $K$ is

$$
E\left(\sum_{i}\left(1-\tau_{i}\right) \alpha_{i} f^{\prime}\left(k_{i}\right) \delta_{i}\right)-r=0 .
$$

Shareholders equate the sum of the expected net-of tax marginal productivity of capital in the two divisions (weighted by the cash flow share allocated to division $i, \delta_{i}$ ) to the opportunity cost $r$. An implicit assumption herein is that, in the absence of external capital injections, the expected overall net-of-tax marginal productivity of capital exceeds $r$. Otherwise, $K=0$ would be optimal. To save on notation, we abstract from this possibility.

An interesting observation is that the share of resources allocated to each division, $\delta_{i}$, is exogenous to shareholders. It is chosen by the headquarter which observes the productivity of the divisions and determines the share, depending on the tax rate differential and productivity realizations, c.f. (6). All these relative investment considerations are independent of the amount of external finance. However, by selecting $K$, shareholders effectively choose the overall size of the internal capital market $\hat{X}$, as implicitly defined by (30). The required size of $K$ residually follows from $K=\hat{X}-x_{1}-x_{2}$. This has implications for how effort choices affect MNE 
profits. Given (30), a rise in the tax rate $\tau_{i}$ reduces the marginal return to capital injections and thus the optimal size of the internal capital market $\hat{X}$. Effort choices of division managers and the internally generated cash flow respond as well, c.f. Lemma 1 . But $\hat{X}$ is insensitive to how internally generated cash flow $x_{1}+x_{2}$ changes. Any change is absorbed by adjustments in capital injections $K$ so as to satisfy (30). For instance, when internal cash flow rises, the overall net-of-tax marginal productivity of capital falls below $r$ and, in order to restore (30), capital injections $K$ will be reduced.

Lemma 4: Assuming $K>0$, the size of the internal capital market is independent of the level of managerial effort and its impact on internal cash flow. In particular, the tax-induced change in external capital is

$$
\frac{d K}{d \tau_{i}}=\frac{d \hat{X}}{d \tau_{i}}-\frac{d\left(x_{1}+x_{2}\right)}{d \tau_{i}}
$$

where $d \hat{X} / d \tau_{i}<0$ is implicitly defined by (30) and $d\left(x_{1}+x_{2}\right) / d \tau_{i}$ follows from Lemma 1.

The governments decide on taxes, anticipating the responses of shareholders, the headquarter and managers. The associated external effect of country $i$ 's tax policy on welfare in country $j$ is (15). As before, the equilibrium change in expected MNE profits is (16), comprising a negative mechanical effect and a behavioral effect due to effort changes, as summarized by Lemma 1. Behavioral responses of MNE profits that follow from external capital injections and the ex-post redistribution of capital are absent since $K$ as well as $k_{1}$ and $k_{2}$ are optimally chosen by shareholders and the headquarter, respectively. The change in country $j$ 's tax base follows from (17), with $X$ being substituted by $\hat{X}$. It reflects the redistribution of capital, given $\hat{X}$, and the change in the size of the internal capital market, as measured by $d \hat{X} / d \tau_{i}$. Different to Section 4, the capital budget of the MNE unambiguously shrinks with variable external capital. Given (30), the response $d \hat{X} / d \tau_{i}<0$ now captures the desire of shareholders to adjust capital injections because a tax rise $d \tau_{i}>0$ renders investments in division $i$ less profitable (net of tax). Since the reduction in $\hat{X}$ reduces the amount of capital the two divisions receive through the internal capital market (though at different amounts), a tax rise generates a negative fiscal externality through the adjustment in $\hat{X}$. This holds independently of how internal cash flow $x_{1}+x_{2}$ changes, c.f. Lemma 4 . Hence, 
Proposition 6: Assume $K>0$. Following a tax rise in country $i$, the externality on shareholder wealth in country $j$ depends on changes in internal efficiency costs, as predicted by Lemma 1. However, the tax base externality on country $j$ is independent of the effects of taxes on managerial effort choices. They are neutralized by adjustments in the amount of external capital. Still, the size of the internal capital market, as measured by $\hat{X}=K+x_{1}+x_{2}$, reduces in response to a tax rise which in itself generates a tendency to overtax profits in country $i$.

The novel feature of Proposition 6 is that external finance insulates the fiscal externality from internal efficiency costs. Compared to a situation with no external finance, where the effort-related tax base externality is ambiguous in sign, this reinforces the tendency to overtax profits at source.

As a corollary to Proposition 6, when the fiscal effect of tax rate changes is the dominant force for domestic welfare effects (since domestic MNE ownership is miniscule, for instance ${ }^{37}$ ), a higher tax rate in a competing country possibly reduces tax revenues and welfare at home. From (6) with $X$ being replaced by $\hat{X}=K+x_{1}+x_{2}$, the sign of the expected tax revenue change at home is

$$
\operatorname{sign}\left(\tau_{i} \frac{d E\left(T B_{i}\right)}{d \tau_{j}}\right)=\operatorname{sign}\left(\frac{E\left(\Delta_{i} d \delta_{i} / d \tau_{j}\right)}{E\left(\Delta_{i} \delta_{i}\right)}+\frac{d \hat{X} / d \tau_{j}}{\hat{X}}\right),
$$

where $\Delta_{i}=\alpha \beta k_{i}^{\beta-1}$. The possibility of a negative spill-over becomes relevant when the internal reallocation of capital is not too sensitive to differences in tax rates, i.e. $d E\left(\delta_{i}\right) / d \tau_{j}>0$ is small. Given the implied low degree of tax avoidance through the headquarter, shareholders will more starkly reduce the scale of MNE operation, as measured by $\hat{X}$, after a rise in the competing country's tax rate. ${ }^{38}$ Consequently, the size of the domestic division and with it the domestic profit tax base become smaller. The fiscal externality turns negative in sign, consistent with the empirical finding in Becker and Riedel (2012).

We should note that effort changes still matter for shareholders. The dark side of internal capital markets reduces firm value which shareholders might neutralize by costly capital

\footnotetext{
${ }^{37}$ For instance, the ownership distribution might be highly skewed across the two countries. MNE owners might also live outside the countries that host the MNE, as frequently observed in practice. In the model, allowing for third-country ownership would require $\gamma_{1}+\gamma_{2} \leq 1$ and $\gamma_{i} \in[0,1]$. The generalization leaves the results in the previous sections qualitatively intact.

${ }^{38}$ The sets of structural parameters that govern the two behavioral responses do not completely overlap. The interest rate $r$ influences $d \hat{X} / d \tau_{j}$, but not $d E\left(\delta_{i}\right) / d \tau_{j}$. In principle, this renders the interplay between the tax sensitivity of internal capital reallocations and capital injections ambiguous in sign and examples can readily be constructed in which one or the other response dominates in its effect on tax revenues.
} 
injections. However, given that shareholders optimally choose the scale of external finance, the tax-induced effect of capital injections on shareholder wealth vanishes, which only insulates tax base changes but not shareholder wealth from effort changes. ${ }^{39}$

\section{Conclusion}

This paper analyzes how tax policy diffuses through internal capital markets and how governments respond to it in their choice of fiscal policy. Unlike previous literature on multinational taxation, this paper accounts for one significant concern of MNEs in reality: the efficiency costs of internal capital markets. Tax avoidance by a MNE interacts with these non-tax costs and may induce governments to choose unorthodox policies in fiscal competition. In particular, profit taxes influence effort provision by division managers. It thereby impacts on the internal cash flow, for which divisions compete in the internal capital market, on the decision to set up an internal capital market and on incentives of shareholders to inject capital. The tax effects that work through effort choices might lead to inefficiently high profit taxes and to an inefficiently low provision of infrastructure. In that sense, internal efficiency costs might counteract the downward pressure on taxes and upward pressure on infrastructure spending in fiscal competition. We develop the results in a setting in which managers are only intrinsically motivated. The results remain unchanged when intrinsically-motivated division managers are also extrinsically motivated through incentive pay, see Appendix A.2.

Multiple extensions are possible. For instance, we focus on a specific type of internal efficiency costs and how it relates to multinational firm behavior. Arguably, other profit shifting devices such as the strategic pricing of intra-firm trade will complement the tax-avoidance behavior that is analyzed in this paper. Transfer pricing might equally incur internal efficiency costs that interact with policy choices in important ways. Second, a recurrent theme in the literature on fiscal competition is how a country's tax base is related to profits of the MNE, see Gordon and Wilson (1986), Kind et al. (2005), and Nielsen et al. (2010), for instance. While the principle of separate accounting, which we adopt in this paper, is the dominant rule for MNEs with cross-national operations, there are policy discussions in the European Union about adopting a formula-based apportionment rule instead. In our model, capital weights can be used to implement such a formula-based system. An analysis of the relative efficiency effects of the two

\footnotetext{
${ }^{39}$ More formally, differentiating shareholder wealth $E(\pi)-r K$ w.r.t. $\tau_{i}$, while noting (5), (30) and that $X$ is replaced by $\hat{X}$, leaves (16) as the change in shareholder wealth.
} 
systems is analytically involved, however. A focus on symmetric tax competition equilibria, as commonly adopted in the literature, would eliminate the role of internal efficiency costs for tax competition in our setting. ${ }^{40}$ Hence, such a comparison must be pursued for asymmetric equilibria. We leave a formal analysis of these and other interesting extensions to future research.

\section{A Appendix}

\section{A.1 Derivation of Effort Responses (13) and Cash Flow Change (14)}

Denoting

$$
\bar{\delta}_{i}=\left(1+\left(\frac{\left(1-\tau_{j}\right) \underline{\alpha}}{\left(1-\tau_{i}\right) \bar{\alpha}}\right)^{\frac{1}{1-\beta}}\right)^{-1} \text { and } \underline{\delta}_{i}=\left(1+\left(\frac{\left(1-\tau_{j}\right) \bar{\alpha}}{\left(1-\tau_{i}\right) \underline{\alpha}}\right)^{\frac{1}{1-\beta}}\right)^{-1}
$$

as the share of cash flow which is allocated to the high-performing division and low-performing division in country $i$, we can use (6) to write the first-order condition (11) as

$$
\theta\left(p \bar{\delta}_{1} a_{1}+(1-p) \underline{\delta}_{1} a_{1}\right)-\omega e_{1}=0 .
$$

Differentiating (34) w.r.t. $\tau_{i}$ and rearranging we get

$$
\frac{d e_{1}}{d \tau_{i}}=\frac{\theta}{\omega}\left(p \frac{d \bar{\delta}_{1}}{d \tau_{i}} a_{1}+(1-p) \frac{d \underline{\delta}_{1}}{d \tau_{i}} a_{1}\right) .
$$

Analogously, we find

$$
\frac{d e_{2}}{d \tau_{i}}=\frac{\theta}{\omega}\left(p \frac{d \underline{\delta}_{2}}{d \tau_{i}} a_{2}+(1-p) \frac{d \bar{\delta}_{2}}{d \tau_{i}} a_{2}\right) .
$$

Note, from (33), that $\operatorname{sign}\left\{d \bar{\delta}_{i} / d \tau_{j}\right\}=\operatorname{sign}\left\{d \underline{\delta}_{i} / d \tau_{j}\right\}<0$ if $i=j$ and $\operatorname{sign}\left\{d \bar{\delta}_{i} / d \tau_{j}\right\}=\operatorname{sign}\left\{d \underline{\delta}_{i} / d \tau_{j}\right\}$ $>0$ if $i \neq j$. Thus, (13) holds.

Using the individual effort responses derived above, total cash flow $X=a_{1} e_{1}+a_{2} e_{2}$ changes as follows:

$$
\begin{aligned}
\frac{d X}{d \tau_{i}} & =a_{1} \frac{d e_{1}}{d \tau_{i}}+a_{2} \frac{d e_{2}}{d \tau_{i}} \\
& =\frac{\theta}{\omega}\left(p\left(\frac{d \bar{\delta}_{1}}{d \tau_{i}} a_{1}^{2}+\frac{d \underline{\delta}_{2}}{d \tau_{i}} a_{2}^{2}\right)+(1-p)\left(\frac{d \underline{\delta}_{1}}{d \tau_{i}} a_{1}^{2}+\frac{d \bar{\delta}_{2}}{d \tau_{i}} a_{2}^{2}\right)\right) .
\end{aligned}
$$

Consider first $a_{1}=a_{2}$. Since, from (33), $\bar{\delta}_{i}+\underline{\delta}_{j}=1$ and thus $d \bar{\delta}_{i} / d \tau_{i}+d \underline{\delta}_{j} / d \tau_{i}=0$, the cash flow response $d X / d \tau_{i}(37)$ is zero.

\footnotetext{
${ }^{40}$ In our basic setting, countries may differ in terms of $\gamma_{i}, p, \lambda_{i}$ and $a_{i}$. Simplifying the analysis by imposing symmetry, i.e. $p=\gamma_{i}=0.5, \lambda_{1}=\lambda_{2}$, and $a_{1}=a_{2}$, eliminates equilibria in which the disincentive effect of internal capital markets interacts with policy choices. These equilibria only prevail when $a_{1} \neq a_{2}$.
} 
Now, consider $a_{1}>a_{2}$. Since $d \bar{\delta}_{i} / d \tau_{i}+d \underline{\delta}_{j} / d \tau_{i}=0$, total cash flow decreases if the response (37) is evaluated for $i=1$ and increases if the response is evaluated for $i=2$. Hence, (14) holds.

\section{A.2 Managerial Incentive Wages}

In this appendix, we extend the model by allowing for incentive wages. For analytical simplicity, we consider a discrete managerial effort model, which is widely used in the literature on internal capital markets and, more generally, on corporate finance as well as in applications of corporate agency models in public finance, see Holmstrom and Tirole (1997), Elitzur and Mintz (1996), Inderst and Laux (2005), Tirole (2006) and Egger et al. (2012), among others. ${ }^{41}$ A model with incentive pay and continuous managerial effort is available upon request. In the more complex framework, the results in the main part of the paper remain unchanged as well.

Managers exert effort $e_{i} \in\left\{e_{i}^{h}=1, e_{i}^{l}=0\right\}, i=1,2$. Division cash flow is $x_{i}=a_{i} e_{i}+\bar{x}$ with $a_{i}, \bar{x}>0$. The cost of exerting effort $\phi\left(e_{i}\right)$ is $\omega>0$ if $e_{i}=e_{i}^{h}$ and zero otherwise. The manager receives a wage payment $w_{i} \in\left\{w_{i}^{h}, w_{i}^{l}\right\}$. The optimal wage contract for manager $i$ is chosen at stage 0.5 of the sequence of events and is conditioned on the level of cash flow $x_{i}$. It is a sufficient statistic for incentive provision (Holmstrom, 1979). Note, division profits are uncertain ex-ante. The productivity realization is unrelated to effort choices and conditioning wages on division profits only adds noise to the performance measure. With a high level of cash flow $x_{i}^{h}=a_{i}+\bar{x}$, the wage payment is $w_{i}^{h}$, while it is $w_{i}^{l}$ when $x_{i}^{l}=\bar{x} . w_{i}^{h}$ is chosen so as to incentivize the manager to exert a high level of effort. ${ }^{42}$ Utility of the division manager is $u_{i}=\theta E\left(k_{i}\right)+w_{i}-\phi\left(e_{i}\right), \theta>0$. Following (6), the incentive compatibility constraint of division manager 1 is

$$
\theta\left(p \bar{\delta}_{1} a_{1}+(1-p) \underline{\delta}_{1} a_{1}\right)+w_{1}^{h}-\omega \geq w_{1}^{l} .
$$

where $\bar{\delta}_{1}:=\bar{k}_{1} / X$ and $\underline{\delta}_{1}:=\underline{k}_{1} / X$. Assuming that the manager has a reservation utility of zero, the participation constraint is $u_{1}=0$. Combining this insight with the incentive-compatibility

\footnotetext{
${ }^{41}$ The aggregate implications of public policy in the model with continuous effort, which we use in the main part of the paper, are similar to the aggregate outcome of a model with discrete effort choices and heterogeneous MNEs. For instance, MNEs and their divisions may exhibit cross-sectional heterogeneity in the cost of effort provision, $\omega$, or the preference for empire-building, $\theta$. With a sufficiently large number of MNEs, aggregate divisional capital allocations vary continuously with the amount of taxes and infrastructure, similar to the model in the main part of this paper.

${ }^{42}$ Implicit to the analysis is the assumption that, from the shareholders' perspective, it is optimal to induce a high effort level. That is, the increment to the cash-flow pool is positive. A sufficient condition for the increment to be positive is $a_{i}>\omega$.
} 
constraint (38), which holds as an equality at the optimum, incentive wages are $w_{1}^{l}=0$ and

$$
w_{1}^{h}=\omega-\theta\left(p \bar{\delta}_{1}+(1-p) \underline{\delta}_{1}\right) a_{1}
$$

The intrinsic motivation of the manager substitutes for monetary incentives. The higher the utility that manager 1 derives from the division's increment in capital when exerting effort, $\theta\left(p \bar{\delta}_{1}+(1-p) \underline{\delta}_{1}\right) a_{1}$, the more intrinsically motivated the manager. The wage payment $w_{1}^{h}$ can be lowered in response.

The incentive-compatibility condition for division manager 2 is analogous in structure to (38). The optimal wage scheme is $w_{2}^{l}=0$ and

$$
w_{2}^{h}=\omega-\theta\left(p \underline{\delta}_{2}+(1-p) \bar{\delta}_{2}\right) a_{2}
$$

Cash flow that can be distributed between the two divisions is now $x_{1}+x_{2}$ corrected for the wage payments that need to be financed out of the divisions' cash flow. Hence, the size of the internal capital market is $X=\sum_{i=1,2}\left(x_{i}-w_{i}\right)$. Note, from (39) and (40), incentive wages will not eliminate the dark side of internal capital markets, see also Brusco and Panunzi (2003), Motta (2003) and Inderst and Laux (2005), for instance. In the absence of the managerial disincentive effect (i.e., $\bar{\delta}_{i}=\underline{\delta}_{i}=1$ ), wages are lower and the amount of internal cash flow $X$ is higher in response.

MNE profit and the tax base are as before, with $X=\sum_{i=1,2}\left(x_{i}-w_{i}\right)$ now being the relevant measure of the cash flow pool. One of the noteworthy implications of this extension is that, given the manager's participation constraint is binding, utility of the manager does not need to be included in the welfare analysis. The metric (7) provides a comprehensive measure of welfare, independently of where the manager resides.

Effect of taxes Differentiating $X=\sum_{i=1,2}\left(x_{i}-w_{i}\right)$ w.r.t. $\tau_{j}$, while noting (6), (39), and (40), after some rearranging, yields

$$
\frac{d X}{d \tau_{j}}=\left(a_{1}-a_{2}\right)\left(p \frac{d \bar{\delta}_{1}}{d \tau_{j}}+(1-p) \frac{d \underline{\delta}_{1}}{d \tau_{j}}\right) .
$$

From (6), the response in $X$ is negative (positive) if $a_{j}>(<) a_{i}$, as in the absence of incentive wages, c.f. Lemma 1. Consequently, the findings in Proposition 2 equally hold with monetary incentive provision. 
Effect of infrastructure Differentiating $X=\sum_{i=1,2}\left(x_{i}-w_{i}\right)$ w.r.t. $a_{1}$ and using (39) and (40) yields

$$
\frac{d X}{d a_{1}}=1+\theta\left(p \bar{\delta}_{1}+(1-p) \underline{\delta}_{1}\right)>0
$$

Two effects are responsible for the positive response in the size of the internal capital market $X$. First, a higher $a_{1}$ makes manager 1 more productive in generating cash flow. Second, given that manager 1 receives more capital through the internal capital market when exerting effort $e_{1}^{h}$, manager 1 is more intrinsically motivated to exert effort. The associated savings in his wage payment is $\theta\left(p \bar{\delta}_{1}+(1-p) \underline{\delta}_{1}\right)$. The change in $X$ when $a_{2}$ rises is analogous in structure.

As such, a higher level of $a_{i}$ increases the size of the internal capital market which spills over to division $j$ through higher internal capital allocations. Shareholder wealth and the tax base in country $j$ increase. The implications are the same as summarized in Lemma 2 and Proposition 3 .

To consider the second type of infrastructure spending, we replace $\alpha$ in (2) by $\tilde{\alpha}_{i} A_{i}$ where $A_{i}$ is a policy variable and $\tilde{\alpha}$ is a stochastic term which has the same properties as in Section 5. Inserting $\alpha_{i}=\tilde{\alpha}_{i} A_{i}$ into (5) shows that, since an increase in $1-\tau_{i}$ is equivalent to a rise in $A_{i}$ in terms of the impact on divisional capital budgets, $d \bar{\delta}_{j} / d \tau_{i}=-d \bar{\delta}_{j} / d A_{i}$ and $d \underline{\delta}_{j} / d \tau_{i}=-d \underline{\delta}_{j} / d A_{i}$, $i, j=1,2$. Using this insight coupled with $X=\sum_{i=1,2}\left(x_{i}-w_{i}\right),(39)$ and (40), we find

$$
\frac{d X}{d A_{i}}=-\frac{d X_{i}}{d \tau_{i}}
$$

The effect of higher infrastructure provision $A_{i}$ is opposite in sign to the effect of a higher profit tax, $\tau_{i}$. This relationship underlies the result in Proposition 4. Hence, the findings reported in Proposition 4 also apply in the setting with incentive wages.

Extensive margin Managers of stand-alone divisions are more intrinsically motivated. Their incentive constraint is (38) where $\delta_{i}$ takes the value of unity. As such, the wage rate $w_{i}^{h}$ is lower than in the presence of an internal capital market, being equal to $w_{i}^{h}=\omega-a_{i}$. Managerial incentives are not diluted by an ex-post adjustment in capital allocations and the choice to set up an internal capital market is influenced by the comparison of the drop in internal cash flow with the rise in profits when capital investments in the two divisions adapt to the productivity of the divisions. Hence, imposing the model structure w.r.t. the distribution of the productivity differential $\Delta=\bar{\alpha}-\underline{\alpha}$ (as in Section 6) and noting (41), tax rate changes yield the same 
implications for the incentive to set up an internal capital market, as summarized in Lemma 3 and Proposition 5.

External finance With external finance, the size of the internal capital market is $\hat{X}=K+$ $\sum_{i=1,2}\left(x_{i}-w_{i}\right)$. Note that managerial effort choices do not depend on $K$, c.f. (39) and (40). The choice of the level of $K$ follows from maximizing (29) and the associated first-order condition is (30). As explained above, the first-order condition implicitly fixes $\hat{X}$ and changes in $\sum_{i=1,2}\left(x_{i}-\right.$ $w_{i}$ ) are absorbed by adjustments in $K$. Thus, Lemma 4 and Proposition 6 apply. The intuition is that shareholders channel external resources to division through the headquarter, which has superior information about productivity and adds value to the MNE by 'winner-picking'. This also applies with incentive-based wages for managers.

\section{References}

[1] Acemoglu, D., P. Aghion, C. Lelarge, J. van Reenen and F. Zilibotti (2007), Technology, information, and the decentralization of the firm, Quarterly Journal of Economics, 122, $1759-1799$.

[2] Antràs, P., M. Desai, and F.C. Foley (2009), Multinational firms, FDI flows, and imperfect capital markets, Quarterly Journal of Economics, 124, 1171-1219.

[3] Becker, J. and N. Riedel (2012), Cross-border tax effects on affiliate investment - evidence from European multinationals, European Economic Review, 56, 436-450.

[4] Berger, P. and E. Ofek (1995), Diversification's effect on firm value, Journal of Financial Economics, 37, 39-65.

[5] Black, D.A. and W.H. Hoyt (1989), Bidding for firms, American Economic Review, 79, 1249-1256.

[6] Brusco, S. and F. Panunzi (2005), Reallocation of corporate resources and managerial incentives in internal capital markets, European Economic Review, 49, 659-681.

[7] Bucovetsky, S. (1991), Asymmetric tax competition, Journal of Urban Economics, 30, 167181.

[8] Bucovetsky, S. and A. Haufler (2008), Tax competition when firms choose their organizational form: Should tax loopholes for multinationals be closed?, Journal of International Economics, 74, 188-201.

[9] Chen, K.P. and C.Y.C. Chu (2005), Internal control versus external manipulation: a model of corporate income tax evasion, RAND Journal of Economics, 36, 151-164.

[10] Crocker, K.J. and J. Slemrod (2005), Corporate tax evasion with agency costs, Journal of Public Economics, 89, 1593-1610. 
[11] Desai, M. and D. Dharmapala (2006), Corporate tax avoidance and high-powered incentives, Journal of Financial Economics, 79, 145-179.

[12] Desai, M. and D. Dharmapala (2009), Corporate tax avoidance and firm value, Review of Economics and Statistics, 91, 537-546.

[13] Desai, M., C.F. Foley, and J.R. Hines (2005), A multinational perspective on capital structure choice and internal capital marktes, Journal of Finance, 59, 2451 - 2487.

[14] Duchin, R. and D. Sosyura (2013), Divisional managers and internal capital markets, Journal of Finance, 68, 387-429.

[15] Egger, P., C. Keuschnigg, V. Merlo and G. Wamser (2012), Corporate taxes and internal borrowing within multinational firms, mimeo, ETH Zurich.

[16] Egger, P., W. Eggert, and H. Winner (2010), Saving taxes through foreign plant ownership, Journal of International Economics, 81, 99-108.

[17] Elitzur, R. and J. Mintz (1996), Transfer pricing rules and corporate tax competition, Journal of Public Economics, 60, 401-422.

[18] Gertner R. and D. Scharfstein (2013), Internal capital markets, in: R. Gibbons and J. Roberts, eds., The Handbook of Organizational Economics, Princeton University Press, chapter 16.

[19] Glaser, M., F. Lopez-de-Silanes, and Z. Sautner (2012), Opening the black box: internal capital markets and managerial power, Journal of Finance, forthcoming.

[20] Gordon, R. and J.D. Wilson (1986), An examination of multijurisdictional corporate income taxation under formula apportionment, Econometrica, 54, 1357-73.

[21] Gresik, T. (2001), The taxing task of taxing transnationals, Journal of Economic Literature, $39,800-838$.

[22] Griffith, R., J.R. Hines and P.B. Sørensen (2010), International capital taxation, in: James A. Mirrlees, Stuart Adam, Timothy Besley, Richard Blundell, Steve Bond, Robert Chote, Malcolm Gammie, Paul Johnson, Gareth D. Myles, and James Poterba, eds., Dimensions of Tax Design: the Mirrlees Review, Oxford University Press, chapter 10.

[23] Grossman, G., E. Helpman, and A. Szeidl (2006), Optimal integration strategies for the multinational firm, Journal of International Economics, 70, 216-238.

[24] Haufler, A. and I. Wooton (2010), Competition for firms in an oligopolistic industry: the impact of economic integration, Journal of International Economics, 80, 239-248.

[25] Haufler, A. and G. Schjelderup (2000), Corporate tax systems and cross country profit shifting, Oxford Economic Papers, 52, 306-325.

[26] Hindriks, J., S. Peralta, and S. Weber (2008), Competing in taxes and investment under fiscal equalization, Journal of Public Economics, 92, 2392-2402.

[27] Hines, J. (1997), Tax policy and the activities of multinational corporations, in Auerbach, A. (Ed.) Fiscal Policy: Lessons from Economic Research. Cambridge: MIT Press, 401-445. 
[28] Holmstrom, B. (1979), Observability and moral hazard, Bell Journal of Economics, 10, 74-91.

[29] Holmstrom, B. and J. Tirole (1997), Financial intermediation, loanable funds, and the real sector, Quarterly Journal of Economics, 112, 663-691.

[30] Hubbard, R. and D. Palia (1999), A reexamination of the conglomerate merger wave in the 1960s: An internal capital markets view, Journal of Finance, 54, 1131-1152.

[31] Huizinga, H. and S.B. Nielsen (1997), Capital income and profit taxation with foreign ownership of firms, Journal of International Economics, 42, 149-165.

[32] Inderst, R., and H.M. Müller (2003), Internal versus external financing: an optimal contracting framework, Journal of Finance, 58, 1033-1062.

[33] Inderst, R. and C. Laux (2005), Incentives in internal capital markets, RAND Journal of Economics, 36, 215-228.

[34] Keen, M. and M. Marchand (1997), Fiscal competition and the pattern of public spending, Journal of Public Economics, 66, 33-53.

[35] Kind, H., K.H. Midelfart, and G. Schjelderup (2005), Corporate tax systems, multinational enterprises, and economic integration, Journal of International Economics, 65, 507-521.

[36] Matsusaka, J.G. and V. Nanda (2002), Internal capital markets and corporate refocusing, Journal of Financial Intermediation, 11, 176-211.

[37] Mintz, J. and M. Smart (2004), Income shifting, investment, and tax competition: theory and evidence from provincial taxation in Canada, Journal of Public Economics, 88, 11491168.

[38] Mookherjee, D. (2006), Decentralization, hierachies and incentives: a mechanism design approach, Journal of Economic Literature, 64, 367-390.

[39] Motta, A. (2003), Managerial incentives and internal capital markets, Journal of Finance, $58,1193-1220$.

[40] Nielsen, S.B., P. Raimondos-Møller and G. Schjelderup (2008), Taxes and decision rights in multinationals, Journal of Public Economic Theory, 10, 245-258.

[41] Nielsen, S.B., P. Raimondos-Møller and G. Schjelderup (2010), Company taxation and tax spillovers: Separate accounting versus formula apportionment, European Economic Review, $54,121-132$.

[42] Ozbas, O. and D. Scharfstein (2010), Evidence on the dark side of internal capital markets, Review of Financial Studies, 23, 581-599.

[43] Scharfstein, D. and J. Stein (2000), The dark side of internal capital markets: Divisional rent-seeking and inefficient investment, Journal of Finance, 55, 2537-2564.

[44] Schjelderup, G. and D. Schindler (2012), Debt shifting and ownership structure, European Economic Review, 56, 635-647. 
[45] Stein, J. (1997), Internal capital markets and the competition for corporate resources, Journal of Finance, 52, 111-133.

[46] Tirole, J. (2006), The Theory of Corporate Finance, Princeton University Press, Princeton.

[47] Wilson, J. (1991), Tax competition with interregional differences in factor endowments, Regional Science and Urban Economics, 21, 423-452.

[48] Yeaple, S.R. (2003), The complex integration strategies of multinationals and cross country dependencies in the structure of foreign direct investment, Journal of International Economics, 60, 293-314.

[49] Zodrow, G.R. and P. Mieszkowski (1986), Pigou, Tiebout, property taxation, and the underprovision of local public goods, Journal of Urban Economics, 19, 356-370. 